\title{
NATURAL GAS SUPPLIES FOR TOMORROW
}

\author{
Rex G. Barer* and Card Illig $\dagger$
}

The control sought to be vested in the Federal Power Commission over the price received by the producer and gatherer of natural gas presents one of our most important contemporary problems. The issue, in so far as it affects the independent producer, ${ }^{1}$ is now before the United State Supreme Court in the Phillips case (State of Wisconsin v. Federal Power Commission ${ }^{2}$ ). The issue as it affects natural gas companies has already been passed on in several cases, the soundness from the legal standpoint and wisdom of which are still being debated. ${ }^{3}$

The problem is a fundamental one in so far as natural gas supplies for tomorrow are concerned. The business of producing and gathering natural gas and selling it in or near the field is, under our American system, a private undertaking. The risks and hazards are so great that no one will undertake them if he is held to a return on his investment similar to that received by utility companies with altogether different types of operations and risks. Notwithstanding this, in the past decade through a series of encroachments on the part of the Federal Power Commission and by strained constructions given the Natural Gas Act by the courts, such a limitation on return or income would appear to be sought.

As a basis for understanding the problem presented, it is necessary to describe briefly the nature of natural gas, the operations involved in producing and gathering it, and the competitive and risk-taking characteristics of gas exploration and production.

\section{Nature of Natural Gas}

To the average individual, natural gas is simply a convenient and economic fuel for heating and cooking. However, this simple notion overlooks the fact that there are really two principal types or classifications of natural gas, depending on the state of its existence underground, and that there are a variety of liquid hydrocarbons extracted from natural gas.

- B.A. and LL.B., University of Texas. Member of the Texas bar.

+B.A., Rice Institute; LL.B., University of Texas. Member of the Texas bar.

1 The term "independent producer" is used to refer to a producer or gatherer not otherwise a natural gas company under the Natural Gas Act and not controlled by a natural gas company. It applies to both large and small producers.

205 F. 2d 706 (D. C. Cir. 1953).

Federal Power Comm'n v. Hope Natural Gas Co., 320 U. S. 59I (I944); Colorado Interstate Gas Co. v. Federal Power Comm'n, 324 U. S. 581 (1945). The problem has been the subject of a number of articles. See Berger and Krash, The Status of Independent Producers Under the Natural Gas Act, 30 TEx. L. REv. 29 (I95I); Hines H. Baker, Natural Gas for the Future, The Petroleum Engineer, Feb. 1954, E-2, E-4; Rex G. Baker, A Free Market for Natural Gas Is Essential, a paper delivered before the Annual Meeting of the New Mexico Oil \& Gas Association, on Dec. 2, I953; Charles I. Francis, Federal Regulation of Interstate Shipment and Sale of Gas, Fourtr ANnuar Institure on OiL and Gas Law and Taxation io3 (Southwestern Legal foundation, 1953). 
Broadly, there are two types of gas: (I) Gas produced from wells producing gas only is called "gas-well gas." Production from such wells may contain varying amounts of liquid hydrocarbons known as "gas condensate" or "distillate," so that at the surface the production is partly gas and partly liquid. (2) Gas produced along with oil from an oil well is known as "casinghead gas."

Chemically, natural gas is a complex hydrocarbon mixture consisting essentially of hydrocarbons of the paraffin series but including, in certain instances and in varying proportions, nitrogen, carbon dioxide, sulphur compounds, and occasionally helium. The latter substances are usually considered impurities, and some of them must be removed to make the gas usable. In some instances, sulphur and helium are extracted for commercial use.

Natural gas operations are concerned chiefly with the hydrocarbons contained in the gas. Methane, the lightest of these, is the principal constituent. Ethane, second in order in the series, is usually present in the next largest amount, followed by propane, the third member, and, in the order indicated, iso- and normal butanes, iso- and normal pentanes, and hexane, plus small amounts of heavier constituents. The natural gas which is commonly utilized commercially and domestically for fuel consists almost entirely of methane, with some ethane, propane, and a little butane. Thus, the gas used for fuel is the residue remaining after the raw gas has been processed through separators or in a gasoline plant to extract varying portions of the heavier constituents and the hexane, pentanes, butanes, propane, and even part of the ethane. It is not always economically attractive to strip the raw gas, since the recoverable volume of products in many cases is so limited that processing facilities requiring considerable investment and continuous operating expenses are not warranted.

In processing natural gas in a gasoline plant, the usual products recovered are the natural gasoline fractions and, in addition, butanes, propane and butane-propane mixtures (all sometimes referred to as "liquefied petroleum gases"-or "L.P.G."), and occasionally ethane. Most of the natural gasoline is utilized by refineries in manufacturing finished motor fuel. The major portion of the L.P.G. is consumed in refineries to produce aviation or motor gasolines and synthetic rubber, and in the domestic market for space heating and cooking. The remainder is used in industrial and chemical manufacturing plants. In recent years, the chemical industry has increased its use of propane and ethane as raw feed material for the manufacture of synthetic products, including plastics and certain types of fabrics. Plant products heavier than the natural gasoline fractions usually consist of naphtha, kerosene, and other similar products of low volatility.

\section{Exploration for Natural Gas}

As is the case with oil, natural gas is found in reservoirs beneath the surface of the earth. These reservoirs are subsurface traps, having porous rocks or sand which hold the gas in captivity, because they are sealed off by impervious cap rocks 
through which the gas cannot escape. Those wishing to find or discover gas must seek to find or discover these traps, then drill wells to penetrate the impervious rocks and, upon completing the wells, bring the gas to the surface. All of the operations associated with finding natural gas and drilling discovery wells for its production are referred to as "gas exploration." Operations involved in bringing the gas to the surface through wells after they are drilled and completed in a field or producing area are referred to as "gas production."

Gas exploration is a risk-taking, economically hazardous business. In the past, surface geology yielded information which might reveal the presence of areas favorable to the accumulation of oil and gas. At present, however, the great majority of these areas have been explored and it is practically impossible to find additional favorable prospects in the United States by the use of surface geology alone. A great amount of research has resulted in the invention of a number of instruments, such as the seismograph, the magnetometer, and the gravity meter, which, when properly used, furnish information as to subsurface structures. These instruments are now employed along with subsurface geology to locate possible prospects for oil and gas production. But despite the technical improvements in geologic and geophysical methods for locating favorable structures, only by drilling a well can one determine whether or not oil or gas underlies a location. And before an exploratory operation can be begun, the operator must secure an oil and gas lease or permit to go on the land; and before he can drill his test well he must purchase an oil and gas lease usually with a substantial outlay of money.

The risks involved in gas exploration are indicated by the experience of the industry in drilling wells (known as "wildcat wells") in new areas in the search for petroleum. Wildcat wells are extremely expensive; electric logs must be run, cores and cuttings taken, and numerous tests made to determine the nature of the underground formations. The cost of most wildcat wells ranges from $\$$ roo,000 to more than $\$ 1,000,000$ each. If a test results in a dry hole, the entire investment is lost, unless further drilling leads to a discovery. And more importantly, the odds are against success. Of every nine exploratory wells drilled only one on the average discovers oil or gas, and in the last three years only one in seventy-six found an oil field with a reserve as large as a million barrels. ${ }^{4}$ These risks, hazards, and costs increase many times as it becomes necessary to drill deeper in the search for oil and gas reservoirs and to prospect in the mountains, swamps, and bays, or offshore in the deeper waters of the Gulf or ocean.

\section{The Production and Gathering of Natural Gas}

Production begins when the exploratory well locates a deposit of oil or gas and petroleum is brought to the surface. Production operations themselves involve considerable risks. Many discoveries cannot be profitably operated, because the condi-

-Lahee, Exploratory Drilling in r950, 35 Bult. AM. Ass'N Petroletum Geot. rr23 (June, I95I); Exploratory Drilling in 1951, 36 id. 977 (June, 1952); Exploratory Drilling in 1952, 37 id. I193 (June, 1953). 
tions of the reservoir are poor, the reserves are small, or excessive costs are involved in production. Moreover, in the development of a discovered area, losses often occur in drilling dry holes to define the field. Thus, in many cases a petroleum operator may discover a deposit of oil or gas but may not be warranted economically in bringing it to the surface. In this event, his entire investment may be lost.

As has been said, gas is either produced alone through a gas well or along with oil through an oil well. Where a market exists, gas produced from a gas well is brought to a central point in or near the field by a series of converging pipe lines known as "gathering lines." Equipment for these purposes requires large investments. There the gas may be compressed, dehydrated, purified, and otherwise processed to make it marketable. Where gas is produced along with oil (i.e., "casinghead gas"), the mixture is passed through an installation on or near the lease known as a "separator," where the gas is separated from the oil. In some instances the gas is processed in a casinghead gasoline plant to extract the casinghead gasoline and other liquids. There it may be compressed, also, and otherwise made marketable. The residue or dry gas is then brought to a delivery point in or near the field by additional gathering lines, at which point the gathering process may be said to be completed.

For many years, the price of natural gas was so low and markets so scarce that in many instances the cost of gathering, compression, and other operations necessary to render it salable were in excess of its value. In this situation, producers, after extracting the liquid products that could be readily recovered, found it necessary to burn the gas to dispose of it, since it could neither be stored nor economically utilized. In recent years, however, the technique of processing gas-well gas to recover the liquid products and of returning the residue to the reservoir, known as "gas cycling," has been developed extensively, and has offered a means of conserving gas produced from gas fields where no immediate market exists. The conservation of casinghead gas, however, presented greater difficulties. It is produced along with oil and performs a useful function in moving the oil to the bottom of the well and lifting it through the well bore to the surface. Lately, however, an increase in the market price of natural gas has justified the construction of numerous casinghead gas conservation projects which permit the removal of the liquid products and render the residue or dry gas available for market. A great conservation program on the part of petroleum operators, which has been particularly accelerated since the close of World War II, has resulted in the conservation of a substantial portion of the casinghead gas produced along with oil.

\section{Gas as an Energy Source}

The principal sources of energy in the United States are coal, oil, natural gas, and water power. The increasingly important role of natural gas is particularly striking. While as late as 1920 natural gas supplied only $I / 25$ of the energy consumed in the United States, today it supplies more than $1 / 5$, or half as much as oil and 
more than half as much as coal. ${ }^{5}$ The great increase in the use of natural gas may be visualized also by considering that since $x 93 \mathrm{I}$ the consumption of oil has tripled, that of natural gas has more than quadrupled, and that of coal has remained substantially the same. ${ }^{6}$

The total gas reserves in the United States are now considerable, amounting to more than 2 II trillion cubic feet, being equal in heating value to 35 billion barrels of oil. ${ }^{7}$ What is particularly significant, however, is the change in the relationship between the rate of increase in the demand for natural gas in the United States and the rate of increase in proved gas reserves. This change is particularly apparent in the period since World War II; since I945 while the demand for gas has doubled, proved reserves of gas have increased only by about 40 per cent. In I953, proved reserves of natural gas were only twenty-three times the annual rate of production, which is perhaps as low as is desirable from the standpoint of an assured supply of gas for the future. Should the same rate of growth in demand and proved reserves experienced during the past seven years continue, by 1960 proved reserves would be only sixteen times the annual rate of production. In the light of the tremendous rate of growth in the demand for natural gas, the ratio of proved reserves to annual production will continue to decrease, unless conditions are such as will provide the proper incentives for future exploration and development.

The reason for this situation is revealed when the price of natural gas is compared with the prices of coal and oil. The retail price of natural gas today is approximately the same as it was in 1939 , while during this period the retail prices of coal and heating oil have doubled. Notwithstanding its cleanliness, convenience, and greater efficiency, gas is being sold to the consumers at retail in many large cities, including some important coal-producing states, at a price per million B.t.u.'s

Application of average heat content values (see notes 8,9 , infra) to data published by the Bureau of Mines as to physical quantities of various primary fuels consumed indicates the respective thermal equivalents of consumption from such fuels to be:

\begin{tabular}{lrrc} 
& & \multicolumn{2}{c}{ Trillion British Thermal Units } \\
Oil & 1920 & 1931 & 1953 (Prelim.) \\
Gas & 2,636 & 5,202 & 15,970 \\
Coal & 838 & 1,768 & 8,663 \\
Water Power & 15,504 & 11,227 & 11,839 \\
$\quad$ Total & 738 & 668 & 1,722 \\
\hline
\end{tabular}

\footnotetext{
${ }^{6}$ See note 5, supra.

${ }^{7}$ Proved reserves of natural gas were reported by the American Gas Association to be $2 \mathrm{Ir} .4$ trillion cubic feet on Dec. 3I, I953. American Gas Ass'N, Reports on Proved Reserves (AM. Pet. Institute, 1953). The Bureau of Mines reports that the average heat content of one cubic foot of gas at the well is 1075 British thermal units and that the heat content of a barrel of crude petroleum is 5,800,000 British thermal units. U. S. Dep't of the Interior, Bureau of Mines, Standard Average Heating Values of VARious Fuels (Jan. r950). Thus, 5400 cubic feet of natural gas are equal to a barrel of crude petroleum in terms of heat equivalent and $21 \mathrm{I} .4$ trillion cubic feet are equal to about 39 billion barrels of crude petroleum. On the basis of 6,000 cubic feet of natural gas having the heat equivalent of a barrcl of crude petroleum (the basis frequently used for comparative purposes) $21 \times .4$ trillion cubic feet of gas are equal to about 35 billion barrels of crude petroleum.
} 
which is lower than the price of heating oil or coal. ${ }^{8}$ It is being sold in the field by the producer at a price equal to about one-fourth of the price of fuel oil at Gulf Coast refineries and at about two-fifths of the price of coal at the mine.

\section{Local Regulation of Gas Distribution and Gas Production}

Our economic and governmental system is based on the fundamental principle of freedom of enterprise and upon a minimum of regulation. Government control of an industry or of the price at which a commodity is sold has never been justified, except in the case of a national emergency or in a situation involving some degree of monopoly granted by the government. Such control is generally accepted by common carriers and public utilities, such as railroads, pipe lines, telephone and telegraph companies, and the distributors to the public of electric power and gas. In these cases the government asserts the right to regulate the rates charged, frequently on the basis of cost plus a reasonable return on the investment, in order to protect consumers against inordinate charges.

Until recently there were only two kinds of regulation applied to natural gas: (I) the states and communities regulated the local distribution of gas as a public utility, and (2) the oil and gas producing states have regulated the production of gas in the interest of conservation.

${ }^{8}$ Application of the respective heat contents of gas, coal, and fuel oil (see note 9, infra) to the prices for such fuel per physical unit (from U. S. Bureau of Labor Statistics, Retail Prices and INDEXES FOR FUEL AND ELECTRICITY (Dec. I952)) gives the following comparative prices to the residential customer in certain cities on a heat value basis. The equivalent prices of coal and fucl oil shown in the table were calculated by multiplying the reported coal and fuel oil prices by the ratio of the utilization efficiency of the other two fuels. The respective utilization efficiencies were obtained from Holaday, Albright, Apjohn, and Steffens, Fuels-Their Present and Future Utilization, a paper presented at the 29th Annual Meeting, American Petroleum Institute Refining Division, Chicago, Ill., Nov. 7-10, 1949; Table 7, Efficiency of Utilization of Domestic Heating Fuels:

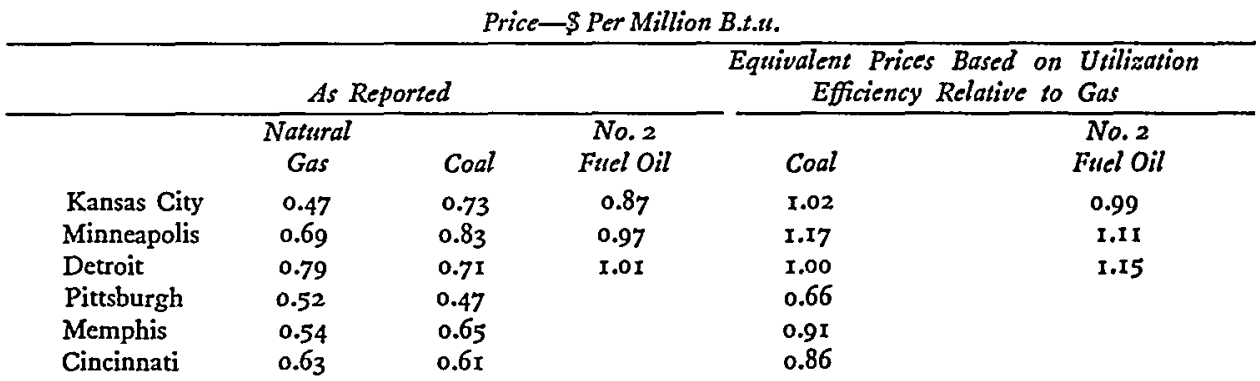

${ }^{9}$ The Bureau of Mines reports average heat contents as follows: residual fuel oil, 6,287,400 B.t.u. per barrel; natural gas at the well, 1075 B.t.u. per cubic foot; and bituminous coal, 26,200,000 B.t.u. per ton. See note 7, supra. Average prices reported for 1952 were: \$1.7563 per barrel for Bunker "C'" fuel oil at Gulf ports-PLATT's OrL PRICE HaNdBooK 97 (1952); \$5.748 per ton for bituminous coal (run of mine) at the mine-U. S. Commerce Dep'T, Business Statistics I69 (table) (1953); 7.8 cents per M.c.f. for natural gas at the well-Bureau of Mines Mineral Market Rep. No. MMS 2229 (Nov. 9, 1953). These prices expressed in terms of heat equivalent were as follows, per million B.t.u.: residual fuel oil, \$0.2793; bituminous coal, \$0.2194; and natural gas, \$0.0726. 


\section{Local Regulation of Gas Distributors}

For many years the local distribution of gas has been regarded as a public utility function subject to regulation by the states or local communities. Such regulation was initially applied to distributors of manufactured gas, which was first used for street lighting and later, with the advent of the electric light, for fuel and heat. The local distributing companies secured grants of franchises to conduct their business and were thereby protected from competition; they obtained rights of way from public authorities for their lines and facilities; and they held themselves out to serve the public. Moreover, they were assured rates which, considering their limited risks, allowed them a moderate return on their investments. The legal theories sustaining such regulations were grounded on these bases and on the further basis that the public had an interest in the business. ${ }^{10}$

Regulation of the local distribution of gas continued when the distributing companies purchased natural gas to enrich their supplies. It is significant, however, that local regulation applied only to the burner tip rate and in no instance extended either to the price paid by the distributor for the coal or oil from which it manufactured gas or to the price it paid for natural gas. ${ }^{11}$

\section{Local Regulation in the Interest of Conservation}

Likewise, the oil and gas producing states, for an extended period, have regulated the production of gas (as well as oil) in the interest of conservation. Gas, like oil, is fugacious by nature and readily moves underground from one property to another as the pressure in the reservoir is reduced by the drilling of a well. However, unlike oil, no practical means exists whereby gas can be stored even temporarily above ground. As a consequence of a low field price and the lack of markets, considerable flaring of both gas-well gas and casinghead gas occurred in the early days of the industry. This situation brought forth a great cooperative effort on the part of operators and state agencies to provide a means by which the physical waste of gas, a limited natural resource, could be avoided and the correlative rights of the several owners in a field protected. These efforts led to the enactment of conservation laws, which are now in effect in most of the oil and gas producing states. Under them, the production of gas-well gas is prohibited unless a market exists; and as a result the waste of gas-well gas has been effectively prevented. Also, through the joint efforts of petroleum operators and state agencies and because of increases in field prices incident to an enlarged demand for gas, the volumes of casinghead gas put to the torch have been substantially reduced through the development of projects for returning gas to the reservoir, stripping it of its liquid products, other conservation measures, and increased field sales. In recent years the oil and gas producing states

${ }^{10}$ See New Orleans Gas Light Co. v. Louisiana Light Mfg. Co., II5 U. S. 650, 658 (1885); IrstoN R. Barnes, The Economics of Publio Utility Regulation c. I (I942): Louis Stotz and Alexander JAMISON, THE History OF THE GAS IndUSTRY 422-423 (I938).

${ }^{11}$ Nowata County Gas Co. v. Henry Oil Co., 269 Fed. 742 (8th Cir. 1920); Humble Oil \& Refining Co. v. Railroad Comm'n, 128 S. W. $2 d 9$ (Tex. Sup. Ct. 1939). 
have given a further impetus to gas conservation by the enactment of laws permitting reservoirs to be operated as a unit and sanctioning cooperative agreements between producers to permit such unit operations. ${ }^{12}$

\section{Federal Regulation}

As gas was brought from the producing areas of the southwest to the consuming areas of the north and east, one unregulated area was found to exist. The pipe line companies, which transported the gas from the fields where it was produced and sold it in increasing volumes to local distributors in other states, were not subject to effective regulation either by the states or municipal governments, because they were engaged in interstate commerce. Local agencies felt that they were handicapped in setting reasonable burner tip rates, because there was no effective regulation over the prices charged by the interstate pipe lines for gas delivered to the local distributors. In the I920's, for example, the State of Missouri sought to prevent an increase in the price of gas to local distributors by a pipe line company which brought the gas in from another state, but was prevented from doing so by the United States Supreme Court in Missouri ex rel. Barrett v. Kansas Natural Gas Company. ${ }^{13}$ The Court held that since the sale involved was in interstate commerce; the state could not regulate it. Therefore, while the State Commission could set the burner tip rate, it must allow the local distributing company, as an operating expense, the price it was required to pay at the city gates for gas transported in interstate commerce and there sold to it. ${ }^{14}$

As a result of the Missouri and other similar cases, an investigation was made by the Federal Trade Commission, which in 1936 called the attention of Congress to the unregulated area or gap mentioned above, referring specifically to the fact situations in the Missouri and other cases. The report recommended that legislation be passed by Congress to regulate the interstate transportation of natural gas and its sale by the transporter to local distributors for resale. ${ }^{15}$

\footnotetext{
${ }^{12}$ Laws in this field have been enacted in the following states: Alabama, Arkansas, California, Florida, Georgia, Illinois, Indiana, Kentucky, Louisiana, Mississippi, New Mexico, North Carolina, Oklahoma, and Texas. See Robert E. Hardwicke, Antitrust Laws et al. v. Unit Operation of Oil or Gas Pools (ז948).

${ }_{13} 265$ U. S. 298 (1924).

14 Cf. Missouri ex rel. S. W. Bell Tel. Co. v. Public Service Comm'n, 262 U. S. 276 (1923); Westẹn Distributing Co. v. Public Service Comm'n, 285 U. S. II9 (1932).

${ }^{15}$ SEN. Doc. No. 92, 7oth Cong., Ist Sess. (1936). Following the filing of the Federal Trade Commission's report, hearings began in 1936 before the Congressional committees on various bills. The most important of these were H. R. II662, 74th Cong., 2d Sess. (1936), the provisions of which were substantially those of H. R. 4008, 75th Cong., Ist Sess. (1937), which later became H. R. 6586 and was passed as the Natural Gas Act of 1938 . The then Solicitor of the Federal Power Commission, Dozier A. DeVane, testified during the hearings that the rate to be paid the producer and gathercr in "arm's-length" sales was not covered by the Act. See Hearings before a Subcommittee of the House Committee on Interstate and Foreign Commerce on H. R. 11662, 74th Cong., 2d Sess. (1936). Sce also, Federal Power Commission v. Panhandle Eastern Pipe Line Co., 337 U. S. 498 (1949), for a résumé of Mr. DeVane's testimony. An "arm's-length" sale may be defined as a sale wherein all the elements conducive to active bargaining and trading are present. It may be contrasted with sales betwcen affiliated or subsidiary companies in which there is presumed to be an absence of bargaining.
} 
To carry out this recommendation, Congress enacted the Natural Gas Act in 1938..$^{18}$ Section $\mathrm{I}(\mathrm{b})$ of the Act defines its application:

The provisions of this Act shall apply to the transportation of natural gas in interstate commerce, to the sale in interstate commerce of natural gas for resale for ultimate public consumption ... and to natural gas companies engaged in such transportation or sale, but shall not apply to any other transportation or sale of natural gas or to the local distribution of natural gas or to the facilities used for such distribution or to the production or gathering of natural gas. (Emphasis supplied.)

The Act was not designed to regulate local distribution at one end or production and gathering at the other end; it was to apply to the gap between these operations by regulating natural gas companies in the interstate transportation of natural gas and the sale thereof to distributors for resale. ${ }^{17}$ Significantly, the Act did not embrace the full area which might have been reached by Congress; it represented only a partial exercise of the power of Congress to regulate interstate commerce. ${ }^{18}$

The Act exempts production and gathering from the Commission's jurisdiction. Since these terms are not defined, they are to be given their ordinary meaning. As trade terms, this meaning is that given to them generally in the oil and gas industry ${ }^{10}$ The concepts of production and gathering generally obtaining in the industry have been previously discussed. It can be seen at once that production and gathering logically include the various processing steps required to extract the liquid products from the gas, and would also logically include the sale of the dry or residue gas.

Encroachments upon the production and gathering exemption have developed along two lines: (I) The Federal Power Commission has. included the production and gathering facilities of the regulated natural gas companies in the rate bases of those companies and has thereby held those companies to a utility return on the depreciated cost of such producing and gathering properties.

(2) A threat of similar regulation has been extended to the independent producer.

${ }^{10} 52$ Stat. 82 (1938), 15 U. S. C. $\$ 717$ et seq. (1946).

37 The report made by the Federal Trade Commission to Congress in 1936, supra, note I5, described the industry as being divided into three parts:

"So broadly speaking, we have in natural gas a situation which, no matter how fully and properly integrated, will present, at both ends problems which are either entirely of local concern or which are of both local and general public concern, and in between a field of interstate transportation where only through the exercise of federal jurisdiction can a proper solution be obtained."

${ }^{18}$ See Interstate Natural Gas Co. v. Federal Power Comm'n, 331 U. S. 682, 690 (x947), where the Court said:

". . . the 'basic purpose' of Congress in passing the Natural Gas Act was 'to occupy this field in which the Supreme Court has held that the states may not act." "

See also Federal Power Comm'n v. Panhandle Eastern Pipe Line Co., 337 U. S. 498, 502 (1949), where the Court said:

“. . the Natural Gas Act did not envisage federal regulation of the entire natural-gas field to the limit of constitutional power."

${ }^{10} \mathrm{Cf}$. O'Hara v. Luckenbach S.S. Co., 269 U. S. 364, 37I (I926), where the Supreme Court said: "If the Act is one passed with reference to a particular trade, business or transaction and words are used which everybody conversant with that trade, business, or transaction, knows and understands to have a particular meaning in it, then the words are to be construed as having that particular meaning, though it may differ from the common or ordinary meaning of the words." 


\section{Regulation of the Natural Gas Companies}

The constitutionality of the Natural Gas Act was sustained in Federal Power Commission v. Natural Gas Pipeline Co., ${ }^{20}$ but the first case involving the establishment of a rate base for a natural gas company was Federal Power Commission $v$. Hope Natural Gas Company. ${ }^{21}$ Hope produced and purchased gas in the State of West Virginia and sold the bulk of it to five purchasers, three of which were affiliates. The purchasing companies received the gas at the West Virginia line and transported it to Ohio and Pennsylvania, where it was distributed. The Commission asserted jurisdiction over Hope because it was engaged in the interstate transportation of gas and in the sale thereof to distributors. It included in Hope's rate base all of the company's producing and gathering properties at their depreciated cost; and the Court by a 5 to 3 decision approved its action despite the provision of Section $x(b)$ that the Commission should not have jurisdiction over production and gathering. The company was permitted to recover only its current operating expenses plus a $61 / 2$ per cent return on the depreciated cost of its producing and gathering properties.

The Court, rejecting the contention of the company that it should be allowed a return on the reproduction value of its facilities, laid down the following rule for determining the reasonableness of rates: ${ }^{22}$

Rates which enable the company to operate successfully, to maintain its financial integrity, to attract capital and to compensate its investors for the risks assumed certainly cannot be condemned as invalid, even though they might produce only a meager return on the so-called "fair value" rate base. (Emphasis supplied.)

Mr. Justice Jackson, in an opinion criticizing the result reached, observed that the gas producing business was not a utility business and that the methods employed by the Commission would discourage the finding of natural gas reserves, saying: $:^{23}$

The heart of this problem is the elusive, exhaustible, and irreplaceable nature of natural gas itself. Given sufficient money, we can produce any desired amount of railroad, bus, or steamship transportation, or communications facilities, or capacity for generation of electric energy, or for the manufacture of gas of a kind. In the service of such utilities one customer has little concern with the amount taken by another, one's waste will not deprive another, a volume of service can be created equal to demand, and today's demands will not exhaust or lessen capacity to serve tomorrow. But the wealth of Midas and the wit of man cannot produce or reproduce a natural gas field. We cannot even repro. duce the gas, for our manufactured product has only about half the heating value per unit of nature's own.

In Colorado Interstate Gas Company v. Federal Power Commission, ${ }^{24}$ the Com-

${ }^{20} 315$ U. S. 575 (1942).

21320 U. S. $59 \mathrm{x}$ (1944). This decision is considered as abandoning the "fair value" basis used in the formation of a rate base, established in Smyth v. Ames, 169 U. S. 466 (1898). Sce McCreery, The Legal Consequences of the Interstate National Gas Company Decision and Related Cases, 19 Miss. L. J. 153,180 (1948).

22320 U. S. at 605.

${ }^{24} 324$ U. S. 58I (1945).

${ }^{23} I d$. at 629 . 
mission, with Court approval in a 5 to 4 decision, took the next step and included the producing and gathering facilities of an affliated company within the rate base of the regulated company and allowed the latter a return similar to that allowed Hope.

Regarding the company's contention that the Commission had no authority to include producing and gathering facilities in the rate base, the Court said:

This is precisely the argument which West Virginia, appearing as amicus curiae advanced in the Hope Natural Gas Co. case. We rejected the argument in that case. . . we adhere to our decision in the Hope Natural Gas Co. case. . . ${ }^{25}$

It is plain . . . that the Commission has authority to fix [Canadian's] . . . wholesale rates. It is obvious that when rates of a utility are fixed the value of its property is affected. ... When a natural gas company which owns producing properties or a gathering system is restricted in its earnings by a rate order, the value of all of its property is affected. Congress of course might have provided that producing or gathering facilities be excluded from the rate base and that an allowance be made in operating expenses for the fair field price of gas as a commodity. Some have thought that to be the wiser course. But we search the Act in vain for any such mandate. ${ }^{20}$

Continuing with reference to Section $I(b)$, the Court said: ${ }^{27}$

Certainly that provision precludes the Commission from any control over the activity of producing or gathering natural gas. For example it makes plain that the Commission has no control over the drilling and spacing of wells and the like.

Here again Mr. Justice Jackson stated that the entire rate base method should be rejected in pricing natural gas, though it might be used in determining transportation costs. He pointed out that orders based upon the Commission's formula would result in three different prices for gas from the same well:28

These orders in some instances result in three different prices for gas from the same well. The regulated company is a part owner, an unregulated company is a part owner, and the landowner has a royalty share of the production from certain wells. The regulated company buys all of the gas for its interstate business. It is allowed to pay as operating expenses an unregulated contract price for its co-owner's share and a different unregulated contract price for the royalty owner's share, but for its own share it is allowed substantially less than either. Any method of rate-making by which an identical product from a single well, going to the same consumers, has three prices depending on who owns it does not make sense to me.

The capricious results obtained in this case are to be observed from the fact that the Commission included five of the most important of the company's leaseholds, embracing approximately 47,000 acres, in the rate base at $\$ 4,244.24-$ something under Ioc an acre. Three such leases were put in the rate base at zero. The company which took the high risk of wildcat exploration was thus allowed a return of $61 / 2$ per cent on nothing for the three leases and a return of less than $\$ 300$ a year on the others. The current market value of the leases was shown to be over $\$ 3,000,000$.

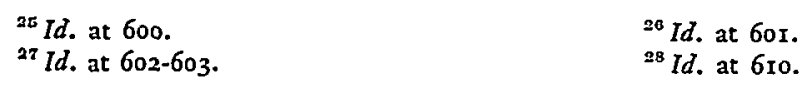


In Cities Service Natural Gas Company $\dot{v}$. Federal Power Commission, ${ }^{20}$ the Commission took an additional step. As in the preceding cases, the Commission included the producing and gathering properties of the company in the rate base at their depreciated cost, but in addition required that there be credited to the company's gas operations an item of $\$ 380,000$, termed as excessive profits realized by an affiliate, Cities Service Oil Company, in extracting liquid products from the natural gas.

The position taken by the Commission in these cases was wholly unnecessary and unsound. Several alternate procedures were available: (I) The Commission could have excluded the production and gathering facilities altogether from the company's rate base; (2) it could have allowed their inclusion at the fair value of the properties; or (3) it preferably could have established a rate formula which would have allowed the company as an expense of operation a price for gas produced by it and taken into the trunk-line equal to the competitive going price in the field or its fair and reasonable value. Any one of these procedures would have protected the distributor and the consumer and would have given assurance to the company, as a producer, that it would receive a return on the fair value of its properties or the equivalent of the competitive field price for its own gas. Any one would have provided an incentive for the company to carry on further gas exploration and development, although in our opinion the inclusion of producing and gathering facilities in the rate base is unsound and contrary to the intent of Congress in passing the Natural Gas Act. The step taken as to Cities Service is even more unreasonable, since from this it would seem to follow that income from oil operations must be credited against gas production where wells produce both oil and gas.

The Commission next took jurisdiction over the price received by a natural gas company for its own gas in an arm's-length sale to another natural gas company which moved the gas interstate for resale. This action was upheld by the Court in Interstate Natural Gas Company v. Federal Power Commission. ${ }^{30}$

Interstate owned gas production in the Monroe, Louisiana, field, and also purchased gas from other producers. It transported both its gas and that acquired from others a distance of about I72 miles into Mississippi. and back into Louisiana where sales were made to local distributing companies for resale and to refiners and other local consumers. In addition, Interstate sold some gas in the Monroe field to three natural gas companies, one of which was an affiliate, and the greater part of this gas was transported by the purchasers to markets in other states. Interstate conceded that part of its operations was subject to the Natural Gas Act, but contended that its sales to the three natural gas companies were made as a part of production and gathering and hence were exempt under Section $I(b)$. The Court rejected Interstate's contention. It observed that some of the gas was produced

${ }^{20}$ I55 F. 2 d 694 (10th Cir. 1946), cert. denied, 329 U. S. 773 (1946), rehearing denied, 329 U. S. 832 (1947).

${ }_{33}^{31}$ U. S. 682 (1947). 
from Interstate's wells and commingled in its pipe line system during the course of its movement with gas purchased by Interstate from other producers. It also observed that the sales were in interstate commerce and were consummated after the gathering process had been completed, saying: $:^{31}$

By the time the sales are consummated, nothing further in the gathering process remains to be done. We have held that these sales are in interstate commerce. It cannot be doubted that their regulation is predominantly a matter of national, as contrasted to local concern.

However, the Court did point out that the Natural Gas Act was not intended to embrace the full measure of Congressional authority, saying (p. 690) that there was reserved to the states the power to regulate the production and gathering of gas in the interest of conservation "or of any other consideration of legitimate local concern." A more precise definition of where federal authority ends and that of the state begins was not indicated.

A halt, however, in the scope of the jurisdiction of the Commission over the regulated company was called by the Supreme Court in its decision in Federal Power Commission v. Panhandle Eastern Pipe Line Company. ${ }^{32}$ Panhandle Eastern, which had included certain unoperated leases within its rate base, created a wholly owned affliate and transferred the leases to the affiliate and subsequently the stock in the affiliate was distributed to its own stockholders. Panhandle apparently sought to realize for its stockholders a greater value for its properties by this means, since the leases which had cost $\$ 160,000$ were apparently capitalized in the new company for $\$ 10,000,000$. The affiliate proposed to sell gas from the leases to supply a local (intrastate) market. The Commission endeavored to enjoin the transaction on the ground that the gas leases and reserves, once having been included within the company's rate base, could not be removed without the Commission's permission. Panhandle Eastern, on the other hand, contended that leases and gas reserves were a part of production and gathering exempted from the Commission's jurisdiction under Section $I(b)$, and therefore that the Commission did not have jurisdiction over the subject matter. The Court so held, saying: ${ }^{33}$

The Commission seeks to distinguish between the activities of production and gathexing, such as drilling, spacing wells, or collecting gas, and the facilities such as reserves and gas leases .... and argues that only the former were excluded from the coverage of the Act. ... In the face of the unambiguous language of the Act and its legislative background we cannot ascribe such a narrow meaning to the words "the production or gathering of natural gas." Of course, leases are an essential part of production.

Regarding the Colorado Interstate case wherein the cost of producing and gathering facilities was used for rate making purposes, the Court said: $:^{34}$

The use of such data for rate making is not a precedent for the regulation of any part of production or marketing.

Another development along a slightly different line had important consequences

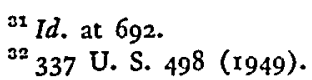

${ }^{33} \mathrm{Id}$. at $504-505$.

${ }^{34}$ Id. at 506 . 
for both the regulated companies and the independent producer. As a part of their gas conservation programs, the States of Oklahoma and Kansas in 1915 and 1935, respectively, enacted legislation which authorized the conservation agencies of those states to act to prevent the waste of natural gas. On this authority, the Oklahoma Corporation Commission heard testimony as to the effect the field price had on gas conservation in the Hugoton field. It was shown that low prices make enforcement of conservation difficult, retard exploration and development, and result in the abandonment of wells before all the recoverable gas has been extracted. There was, in addition, testimony that low prices contributed to an uneconomic rate of depletion and to economic waste of gas. The Commission found that there was no competitive market for gas in the field and that taking gas from the field at less than its economic value resulted in physical waste and in losses to the producer and to royalty owners and to the state in gross production taxes. On the basis of these findings, the Commission ordered that no gas be taken from the field at less than $7 \%$ per Mcf. The validity of this order (and of an order requiring the ratable taking of gas from producers) was sustained by the United States Supreme Court in Cities Service Gas Company v. Peerless Oil \& Gas Company. ${ }^{35}$ The Court held the order valid against the objection that it violated the commerce, due process and equal protection clauses of the Constitution, observing: ${ }^{36}$

A state is justifiably concerned with preventing rapid and uneconomic dissipation of one of its chief natural resources.

We recognize that there is also a strong national interest in natural gas problems. But it is far from clear that on balance such interest is harmed by state regulations under attack here.

Following the principle in the Cities Service-Peerless case, the Supreme Court of Kansas upheld the Kansas statute and a minimum price order of the Kansas conservation agency in Kansas-Nebraska Natural Gas Company v. State Corporation Commission. ${ }^{37}$

Subsequent to these cases, Northern Natural Gas Company made application to the Federal Power Commission to be allowed to include as an operating expense for rate purposes, the price which the order of the Kansas Corporation Commission required to be attributed to gas at the wellhead for gas which the company produced from the Hugoton field and took into its interstate trunk lines. The Commission, however, held that it was not required to allow Northern the minimum value fixed by the Kansas Commission, but that it would allow only the actual cost of the gas involved. The Circuit Court of Appeals, relying on the rate making rule set forth in the Colorado Interstate case, affirmed the Commission's ruling in State Corporation Commission of Kansas v. Federal Power Commission, and the United States Supreme Court refused to review the case. ${ }^{38}$ As a consequence, it

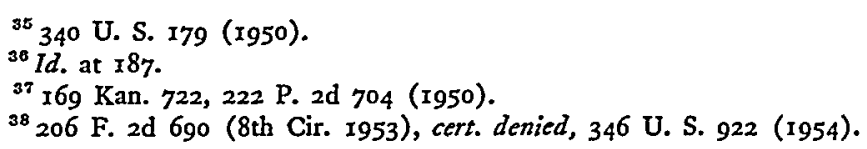


would appear that although the natural gas company may be compelled to pay the minimum price fixed by a state conservation agency for gas purchased in the field where produced, it cannot bring its own gas into the rate base at a like value.

Threat of Regulation of the Independent Producer

In 1940, shortly after the passage of the Natural Gas Act, the Federal Power Commission in In re the Matter of Columbian Fuel Corporation ${ }^{39}$ held that it did not have jurisdiction over sales made by a producer and gatherer which was not an interstate transportation company or affiliated with such a company. After reviewing the language and history of the Act, the Commission said:

To make regulation of producers and gatherers effective under these circumstances would require statutory authority of much wider scope and machinery exceeding that at the disposal of the Commission with its present limited appropriation. ${ }^{40}$

We conclude, therefore, that it was not the intention of Congress to subject to regulation under the Natural Gas Act all persons whose only sales of natural gas in interstate commerce, as in this case, are made as an incident to and immediately upon completion of such person's production and gathering of said natural gas and who are not otherwise subject to the jurisdiction of this Commission.11

Subsequently, in seven additional cases over the years, the Commission held in similar fact situations that it had no jurisdiction over sales made by independent producers. ${ }^{42}$ To have been consistent with these rulings, the Commission, some have observed, should have held that it had no jurisdiction over the sales made by Interstate Natural Gas Company to its non-affliated purchasers. The Interstate case, however, can be explained on at least two grounds: First, Interstate conceded that it was subject to the Commission's jurisdiction as to its other operations. Since by the peculiar language of the Act the Commission is given jurisdiction over "natural gas companies" as well as over transportation in interstate commerce and certain sales for resale in interstate commerce, it might be contended that the jurisdiction over Interstate's sales was justified. Also, as the Court observed, the gas therein involved had been produced and gathered before the sales were consummated, from which an inference can be drawn that the Court did not consider that the sales were made as a part of production and gathering. However, some of the language used in the opinion may be considered at odds with either of these interpretations. The Court, for example, observed that the sales in question "were quite as much in interstate commerce as they would have been had the pipes of the petitioner crossed the state line before reaching the point of sale." ${ }^{33}$ It also said.44

${ }^{30} 2$ F. P. C. 200 (1940).

${ }^{10}$ Id. at $20 \%$.

"1 Id. at 208 .

${ }^{2}$ In re Fin-Ker Oil and Gas Production Co., 6 F. P. C. 92 (1947); In re Chicago Corp., 6 F. P. C. 98 (r947); In re The Kansas-Nebraska Natural Gas Co., 6 F. P. C. 664 (1947); In re R. J. \& D. E. Whelan, 6 F. P. C. 672 (1947); In re La Gloria Corp., 7 F. P. C. 349 (1948); In re General Crude Oil Co., 7 F. P. C. 1024 (1948); In te Superior Oil Co., 7 F. P. C. 627 (1948).

's Interstate Natural Gas Co. v. Federal Power Comm'n, 331 U. S. 682, 687-688 (1947).

"Id. at 693 . 
Unreasonable charges exacted at this stage of the interstate movement become perpetuated in large part in fixed items of cost which must be covered by rates charged subsequent purchasers of the gas, including the ultimate consumer. It was to avoid such situations that the Natural Gas Act was passed.

In 1947 , in order to allay fears of independent producers who were alarmed by the language in the Interstate case, the Commission issued an order to the effect that it would not exercise jurisdiction over sales by such producers, ${ }^{45}$ and in $195^{\circ}$ Congress enacted the Kerr Bill, expressly denying jurisdiction to the Commission in such cases. ${ }^{46}$ This bill was vetoed by the President. ${ }^{47}$ Thereupon the Commission reversed the position it had taken earlier, revoked its 1947 order, and in a new order announced that investigations would be made of sales by independent producers where the price appeared excessive. ${ }^{48}$ It immediately began an investigation of the charges made in sales to natural gas companies by Phillips Petroleum Company for gas in or near the fields where produced. After reviewing these sales, however, in July I95I, the Commission found that under the Act it had no jurisdiction because the sales were made as a part of production and gathering. ${ }^{40}$ This holding was reversed by the Circuit Court of Appeals of the District of Columbia on an appeal taken there by several consumer cities. ${ }^{50}$ As this is written the case is being reviewed by the Supreme Court.

The facts in the Phillips case are significant, and the final decision ultimately to be rendered will have important consequences for independent producers. Phillips was engaged in the oil and gas producing business generally. It produced gas from a number of fields in Texas, Oklahoma, and New Mexico. It moved the gas from wells where produced together with purchased gas to processing plants where the liquid products were removed, and then moved the residue through short lines to points where it was sold to gas pipe line companies for interstate transportation and sale. The points at which the deliveries were made varied between sales. The

${ }^{45}$ Order No. 139, Aug. 7, 1947. The Order stated in part:

"The Commission gives its assurance to independent producers and gatherers of natural gas that they can sell at arm's length and deliver such gas to interstate pipe lines and can enter into contracts for such sale without apprehension that in so doing they may become subject to assertions of jurisdiction by the Commission under the Natural Gas Act."

${ }^{4}$ S. 1498, 81st Cong., Ist Sess. (I949). The Kerr bill amended Sec. I(b) of the Act to exempt from the jurisdiction of the Commission arm's-length sales of gas made by independent produccrs and gatherers as a part of producing and gathering operations. An earlier legislative proposal, the Rizley bill, H. R. 4051, 80th Cong., Ist Sess. (I947), not only would have accomplished the amendment intended by the Kerr bill but in addition (a) would have required the Commission to allow natural gas companies as a separate expense ( $r$ ) the actual price paid for gas in arm's-length transactions with nonaffiliates, and (2) for gas produced by the natural gas companies the reasonable commodity value of such gas in the field or fields where produced; (b) would have precluded the Commission from asserting jurisdiction over companies receiving gas within a state and transporting and distributing it wholly within the state; and (c) would have required the Commission to segregate the regulable from the nonregulable properties of natural gas companies in determining the proper return to be allowed to the property subject to regulation.

${ }^{47}$ H. R. Doc. No. 555, 81st Cong, 2d Sess. (1950).

${ }^{8}$ Order No. 154, July II, I950.

${ }^{18}$ In re Phillips Petroleum Co, F. P. C. Doc. No. G-Ir48, Op. No. 217, 10 F. P. C. 246 (195I).

${ }^{50}$ Wisconsin v. Federal Power Comm'n, 205 F. 2d 706 (D. C. Cir. I953), eert. denied, 346 U. S. 896 (1953), cert. granted, 346 U. S. 934 (1954). 
Commission found as a fact that all of the sales made by Phillips were completed before production and gathering were concluded, or that the sales were so closely associated with production and gathering as to be a part thereof. It consequently held that under Section $I(b)$ it had no jurisdiction to regulate the prices received by Phillips. The Circuit Court of Appeals, however, refused to accept the Commission's finding that the sales were made as a part of production and gathering, stating that the question was a generic one reaching the meaning of the Act. It held that Phillips sold the gas at a time and beyond the place at which production and gathering were complete and after processing had intervened and, relying on the Colorado Interstate and Interstate cases, ${ }^{51}$ held the sales subject to regulation, and stated that the Commission was obligated to fix the price at which Phillips sold.

The fact that the Supreme Court has agreed to review this case is significant. In no other case has the Court determined the question of Federal Power Commission jurisdiction over an independent producer.

\section{Present Situatton}

The outcome of the Phillips case may determine in similar fact situations that the Commission cannot regulate the field prices charged by an independent producer. It may, on the other hand, hold that the Commission has authority to regulate such prices. If the Court holds that the Commission cannot regulate the field prices received by the independent producer, then it may accord to the production and gathering exemption in the Act its intended meaning as applied to such sales. But, the decision in the Phillips case will not in any event free the natural gas company from Federal Power Commission control over the value at which it takes gas from its own producing properties into the trunk line. The Commission in such instances still may allow the regulated company only its costs of production, plus up to a $61 / 2$ per cent return on the depreciated cost of the producing properties from which the gas is delivered.

\section{The Heart of the Issue}

Why is it unsound and not in the public interest for the Federal Power Commission to regulate the price received by the gas producer or, in the case of the regulated company, to hold the return below that of the competitive market value of gas in the field?

Control of the field price is unsound and against the best interests of the consuming public and the general welfare for a number of reasons:

First. Control of the producer's field price was not intended by Congress. The field sale is a necessary incident of production and gathering. The sale is the fruit of the operation without which the value of the reserves and the facilities would be substantially reduced. Hence control of the sales price would be the most effective control possible over operations which are declared outside the Commission's jurisdiction. Considering the language of the Act, the hearings which preceded its en-

\footnotetext{
${ }^{51}$ See notes 24 and 30, supra.
} 
actment, and its legislative history, including statements of proponents of the bill, it seems clear that this measure of control was not intended. The absence of a fact finding by Congress that such regulation was necessary in the public interest makes it very doubtful whether such control can be achieved in accordance with accepted legal principles. ${ }^{52}$

Second. Regulation of the production of natural gas and the price received in the field on a utility basis is wrong in principle. The production of natural gas is a highly risk-taking venture, actively competitive and completely different in character from a public utility business.

A public utility usually operates under a public franchise or certificate of public convenience and necessity. It is granted certain exclusive rights to serve the public, holds itself out to perform these services, dedicates its properties to such a purpose, and secures protection against competition in whole or in part in its field of operation. After its investment is made, it enjoys a fairly stable business with relatively fixed risks and is entitled by law to have its rates regulated so as to recover all costs and yield a reasonable return on the investment.

The business of producing natural gas, whether it be carried on by the independent producer or by a natural gas company, has none of these characteristics. It is highly competitive. There are no franchises or certificates of public convenience or necessity that give one producer a preference or free him from competition with other producers. The risks are high. There is no assurance of any return on the investment made. In fact, the entire amount risked may be lost without any return. There is no holding out to serve the public in a specific operation and no dedication of property to a public use.

The business of producing gas is closely related to the production of oil. They are generally carried on together and are competitive in exploration, the acquisition of leases, the drilling of wells, and obtaining markets. Anyone is free to enter the business without securing permission from a government agency.

To compensate for the high risks, to induce the investment of new capital and the reinvestment of profits, the returns on successful ventures must be attractive. They must be sufficient to pay the expenses of unsuccessful ventures and yield such profit as will induce the operator to risk investment in new ones. The hazards are too great to secure exploration and development on a basis of a fixed percentage return on the investment in successful ventures.

Third. Control of the field price of gas will destroy incentives to find and develop new gas reserves.

Gas supplies for tomorrow depend upon finding new reserves, which in turn is contingent upon enlisting the resourcefulness and initiative of producers. It is clear that no incentive will be provided if the confiscatory rate-making formula of

62 As a condition precedent to government regulation, there must be a finding of fact by the State Legislature or the Congress, as the case may be, with respect to the need for such regulation cither under the police power of the state or under one of the delegated powers of the Congress. Cf. Nebbia v. New York, $29 \mathrm{I}$ U. S. 502 (I934); I6 C. J. S. $1444, \$ 690$. No such finding appears in $\$ 1$ of the Natural Gas Act, which deals with the necessity for the legislation. 
the Hope case is applied and industry is held to a return of $5 \frac{1}{2}$ to $6 \frac{1}{2}$ per cent on the cost of successful ventures. We see proof of this in what has happened to the regulated companies immediately after this formula was established. Whereas in I945 (the year after the Hope decision) natural gas utilities produced 35 per cent of their supplies, their production has accounted for a decreasing proportion in each subsequent year, and in 1952 accounted for less than 15 per cent of their total supplies. Some of the regulated companies have been forced to sell their reserves in order to realize something of their true value. Moreover, the amounts spent by such companies on exploration are negligible compared with expenditures for exploration made by the non-regulated companies.

As against this situation, we have the experience of the petroleum industry which, enjoying a free market for its products, has, through the ingenuity and resourcefulness of its several units, produced ever increasing quantities of oil and petroleum products for the national defense and for civilian use. Competition among the thousands of petroleum operators has resulted in reasonable prices. In like manner, our free competitive system, if allowed to operate, will permit adequate supplies of natural gas to be discovered and produced to serve the expanding needs of our people; and similarly competition among the thousands of natural gas producers and the competition of gas with coal and fuel oil in a free market will hold prices at a reasonable level. The history of American business demonstrates that a free market is the best means of assuring adequate supplies of products at reasonable prices and stimulating producers to greater efficiency and new discoveries. This has certainly been so in the case of natural gas.

Much of the gas moving interstate today was purchased under old contracts entered into many years ago when there was a surplus of gas and when gas was treated as a byproduct not bearing its proper share of exploration and producing costs. Those producers selling at these low prices could not stay in business or continue their search for gas but for the fact that they rely on their oil operations to carry the burden of their exploration and development costs. With the increase in demand, gas must bear its proper share of these costs. The strong demand may inevitably act as a force to raise prices, but these prices will stimulate the development of new supplies, which in turn will operate to keep prices reasonably low.

Price regulation of a competitively produced commodity such as gas thus is not only wrong in principle; it produces evil results. Confiscatory rate formulas which permit only a meager return do not bring forth the creative, vigorous and daring effort which leads to new gas discoveries. Moreover, they injure the interests of the consumer in that they will deprive him of future supplies.

In a word, the dead hand of government regulation and price control would destroy the incentives to develop new gas reserves.

Fourth. Government control of the producer's field price would in time mean higher prices to consumers. 
If we may be guided by the experience of the natural gas companies, Federal Power Commission regulation of the field price of gas may be based on the investment in successful ventures only and no return allowed on the large amounts of capital lost in unsuccessful ventures. If an attempt is made to provide a return on these items, vexing questions immediately arise as to what part of exploration expense, dry hole costs, and surrendered leases should be borne by gas instead of oil, and would doubtless lead to control of oil if any allocation of such items were attempted. Moreover, under such a criterion or standard for determining a proper return, the gas producer would not be able to borrow money to carry on his operations and new discoveries would rapidly diminish. Also, the producer, in order to avoid the consequence of Federal Power Commission regulation, would concentrate on selling his gas in the state where produced, thus reducing the quantity of gas moving interstate. Shortages in gas supplies for interstate markets would result from all of these factors; and these shortages would necessarily mean higher costs of transportation and distribution since, with fixed investments in facilities for these operations, a decline in the volume of business handled means a corresponding rise in the unit costs. The shortage of gas thus brought about by the control of prices would increase the cost of transportation and distribution, which makes up from 85 to 95 per cent of the delivered price to the residential consumer. Thus it is clear that the application of government price control to gas in the field would defeat its alleged purpose of protecting consumers, and in time would actually result in reduced supplies as well as in higher delivered prices.

Fifth. Federal regulation of gas prices will impede gas conservation carried on by the producing states.

The economic basis for the conservation of casinghead gas lies in the availability of markets at adequate prices. If gas is not allowed to be sold for its competitive price in the field, the producer will not construct the expensive gathering and compressing equipment necessary to effect its delivery; nor can he justify investment in the expensive conservation projects necessary for its further conservation and utilization. Actually, the many gas conservation projects which have been completed since the close of World War II are dependent upon the sale of gas at its competitive market price. If the price of gas sold by producers to the interstate lines is to be regulated on the basis of cost, this program will be destroyed. As a consequence, large amounts of casinghead gas which are now being effectively utilized will either be wasted through venting to the air or, if the production is shut in, will be held in the reservoirs. Thus, further investment in interstate gas pipe lines will be discouraged and the volume of gas available to interstate markets will be reduced.

Sixth. Controlling the field price of all gas moving interstate would be an impossible administrative task.

No doubt the Federal Power Commission is reluctant to embark upon a program of regulating the production and gathering of gas generally and the price received by the producer, because it is mindful of the many difficulties and serious problems 
which would arise if it undertook to do so. In 1952 there were only I50 companies classified as natural gas companies reporting periodically to the Commission, while there were nearly 4000 producers selling gas to these companies. An appalling task of administration, maddening delays and restrictions imposed upon producers who must act promptly as their experienced judgment dictates, a considerable increase in personnel, and substantial new appropriations would be involved if the Commission undertook to regulate all these producers. Moreover, there is not enough wisdom in any administrative agency to solve the many administrative problems which would be presented and to evolve a satisfactory formula which would cause sufficient volumes of gas to be discovered and produced to meet future needs.

It can be seen from these considerations that control of the field price of gas by the Federal Power Commission is contrary to the public interest and would defeat the efforts of the gas and petroleum industries to provide gas for tomorrow's needs. The problem is fundamental. It goes to the very heart and core of our American system of private, competitive enterprise. For if a federal agency should fix the price of gas in the field, then there is no reason why it should not also fix the prices of oil and of products of farms, ranches, mines, and mills which enter into commerce.

In the light of these considerations, it is necessary either by judicial decision or by legislation (I) expressly to deny to the Federal Power Commission authority to fix or regulate the price at which the producer or gatherer of natural gas sells his gas to a natural gas company and (2) to require the Commission, in fixing the rates of a natural gas company, to allow as an expense to the company the actual price paid for gas purchased from non-affiliates and the market price or fair and reasonable value in the field for gas produced by the company or acquired from an affiliate. Assurance of these results is a matter of grave concern to producers and consumers alike and to the public. 